\title{
KETERLIBATAN EVENT STAKEHOLDERS PADA KEBERHASILAN EVENT PR
}

\author{
Lidya Wati Evelina \\ Marketing Communication Department, Faculty of Economic and Communication, BINUS University \\ Jln. K. H. Syahdan No. 9, Palmerah, Jakarta Barat 11480 \\ lidiaevelina@yahoo.com
}

\begin{abstract}
The objective of this article is to determine how event organizers collaborate with stakeholders including the media, particular community, sponsors, participants, venue providers, accommodation providers, carteres, legal and finance personnel, production, local trade, transportation providers, government and associations for implementation Public Relations event. This paper discusses about the things that must be done for the cooperation and the benefits of cooperation undertaken. The method used in this paper is qualitative research method based on observations, literature and case studies. The results of this research note that the event organizers or companies can together with the stakeholders (the other party) make an event as mutually beneficial Public Relations. This means that all parties can achieve through the event. At the conclusion of an event Public Relations, all stakeholders involved for their own purposes. Event organizer must ensure that all stakeholders work together effectively in accordance with the agreed schedule and budget. One important feature of the agreement is to maintain a good flow of communication according to the needs of its stakeholders. All information is documented to avoid misunderstandings. Collaboration between stakeholders continuously until the event is completed. Discussion of issues that arise during the event takes place between the committee with various stakeholders is an important thing for the evaluation and response to the events that occurred.
\end{abstract}

Keywords: stakeholders, successfull PR Event

\begin{abstract}
ABSTRAK
Tujuan tulisan ini adalah untuk mengetahui cara event organizer menjalin kerja sama dengan stakeholders, di antaranya adalah media, komunitas tertentu, sponsors, participants, venue providers, accomodation providers, caterers, legal and finance personnel, production, local product, transportation provider, pemerintah, dan asosiasi untuk pelaksanaan event Public Relations. Pada tulisan ini dibahas mengenai hal-hal yang harus dilakukan untuk kerja sama tersebut dan manfaat dari kerja sama yang dilakukan. Metode yang digunakan dalam tulisan ini adalah metode penelitian kualitatif berdasarkan observasi pengamatan, studi pustaka, dan studi kasus. Hasil dari penelitian ini diketahui bahwa event organizer atau perusahaan dapat bersama-sama dengan stakeholders (pihak lain) membuat suatu event Public Relations yang saling menguntungkan. Artinya, semua pihak dapat mencapai tujuan melalui event tersebut. Kesimpulannya, pada sebuah event Public Relations, semua event stakeholders terlibat untuk tujuan mereka masing-masing. Event organizer harus memastikan semua stakeholders bekerja bersama-sama secara efektif sesuai dengan jadwal dan anggaran yang disepakati. Satu hal penting dalam kerja sama tersebut adalah menjaga alur komunikasi yang baik sesuai dengan kebutuhan para stakeholders. Semua informasi didokumentasikan untuk menghindari kesalahpahaman. Kolaborasi antara stakeholders kontinu sampai event selesai terlaksana. Diskusi tentang masalah-masalah yang timbul selama event berlangsung antara panitia dengan berbagai stakeholder merupakan suatu hal penting untuk evaluasi dan respons terhadap peristiwa-peristiwa yang terjadi.
\end{abstract}

Kata kunci: stakeholders, keberhasilan event PR 


\section{PENDAHULUAN}

Public Relations Officer (PRO) suatu perusahaan menggunakan jasa stakeholders untuk menghasilkan sebuah event yang baik. Jumlah anggota dalam Tim dari PRO dalam perusahaan tidak terlalu banyak dan akan mengalami kesulitan untuk menangani semua pekerjaan yang terkait dengan event. Keterlibatan stakeholders akan membantu pelaksanaan event secara profesional.

Pauline (2011) dalam jurnal Internasional menulis bahwa Event Organizer dapat memanfaatkan perekrutan relawan yang sesuai dan strategi untuk mempertahankan mereka. Untuk itu, terlebih dahulu harus memahami titik kepuasan bagi para relawan serta faktor yang mempengaruhi niat mereka menjadi sukarelawan dan memahami motivasi mereka. Penelitian yang dilakukan Pauline adalah sebuah studi ini mengkaji faktor yang memengaruhi kepuasan relawan serta niat untuk tetap sebagai relawan untuk suatu acara golf khusus kaum pria elit di sirkuit Golf Asosiasi Profesional (PGA).

Hasil penelitian menunjukkan bahwa keseluruhan relawan puas dengan pengalaman mereka dan bersedia untuk kembali namun prihatin dengan tingkat komunikasi antara organisasi dan relawan. Penelitian ini juga menemukan bahwa lamanya kesediaan untuk layanan dipengaruhi kepuasan relawan. Penelitian tersebut juga menunjukkan perbedaan yang signifikan antara waktu pertama kali keikutsertaan dan relawan kembali dalam niat mereka untuk terus sukarela untuk acara olahraga selanjutnya. Temuan dalam penelitian tersebut memiliki implikasi untuk tidak hanya memperluas pemahaman teoretis tidak hanya kesukarelaan pada event olahraga, tetapi mengakui bahwa Event Organizer perlu terlibat dalam perekrutan, manajemen, dan retensi relawan untuk kesuksesan pelaksanaan event.

Dengan demikian, terlihat bahwa penyelenggara, dalam hal ini, petugas Public Relations perlu peran serta dari stakeholders. Rumusan masalah dalam tulisan ini adalah (1) Bagaimana host atau tuan rumah bekerja sama dengan stakeholders dalam penyelenggaraan event? (2) Siapa saja dan bagaimana bentuk kerja samanya tergantung dari jenis event? (3) Apa peranan Stakeholders untuk keberhasilan sebuah event $P R$ ?

\section{METODE PENELITIAN}

Penelitian ini menggunakan metode kualitatif. Hasil penelitian didapatkan dari observasi, studi pustaka, dan studi kasus.

\section{HASIL DAN PEMBAHASAN}

Event didefinisikan sebagai suatu kegiatan yang diselenggarakan berkaitan dengan hal-hal penting sepanjang hidup manusia baik yang terikat adat, budaya, tradisi dan agama yang diselenggarakan untuk tujuan tertentu serta melibatkan lingkungan masyarakat yang diselenggarkaan pada waktu tertentu (Noor, 2009: 7). Di sini terlihat jelas penyelenggaraan sebuah event, selain bekerja sama dengan stakeholders, juga harus memerhatikan adat, budaya, tradisi serta agama dari lingkungan tersebut.

Saat ini event perusahaan merupakan agenda penting bagi kegiatan Public Relations sebuah perusahaan sepanjang tahun. Alasannya, event dipandang lebih efektif dibanding dengan aktivitas 
promosi melalui iklan yang biaya pemasangannya lebih mahal dan audiensi tidak diketahui dengan pasti. Perusahaan yang menyelenggarakan event dapat langsung berhadapan dengan calon konsumen atau pelanggannya. Dengan demikian, perusahaan tersebut mengetahui kebutuhan dan keinginan mereka melalui interaksi yang terjadi selama event berlangsung.

Sebuah event di bawah koordinasi Public Relations haruslah berorientasi pada citra perusahaan. Kemudian, event tersebut dinyatakan bermanfaat bila event tersebut berdampak pada perusahaan. Tujuan penelitian ini melihat cara event bisa bekerja sama dengan stakeholders dan mendatangkan keuntungan bagi kedua belah pihak dari segi biaya dan sisi eksposur. Artinya, event yang spektakuler akan diliput oleh berbagai media cetak dan elektronik. Ini menandakan kehadiran dan popularitas perusahaan akan tersebar secara luas ke seluruh penjuru.

Keberadaan stakeholders diperlukan untuk sebuah event karena dapat menghemat banyak hal dari segi biaya, waktu, dan tenaga serta profesionalitas untuk penyelenggaraan event tersebut. Stakeholders adalah suatu entitas yang akan terlibat dalam sebuah event Public Relations (PR). Tingkat pengaruhnya tergantung pada beberapa faktor seperti motivasi personal, power dan otoritas yang dimiliki oleh masing-masing stakeholders. Keterlibatan mereka bisa secara tidak langsung ataupun secara insidental saja. Stakeholders yang akan terlibat bisa dari berbagai kalangan (Mc Cartney, 2010: 261).

Sebuah event organizer dapat saja melibatkan lebih dari 10 stakeholders, yaitu: media, komunitas tertentu, sponsor, participants, venue providers, accomodation providers, caterers, legal and finance personnel, production, local trade, transportation provider, pemerintah dan asosiasi. Setiap stakeholder mempunyai pengetahuan, keahlian, konstituensi, dan modal. Mereka tidak memiliki semuanya untuk mencapai tujuan mereka masing-masing sehingga memerlukan kerja sama dengan pihak event organizer. Berikut ini gambar 10 stakeholders yang terlibat dalam event organizer.

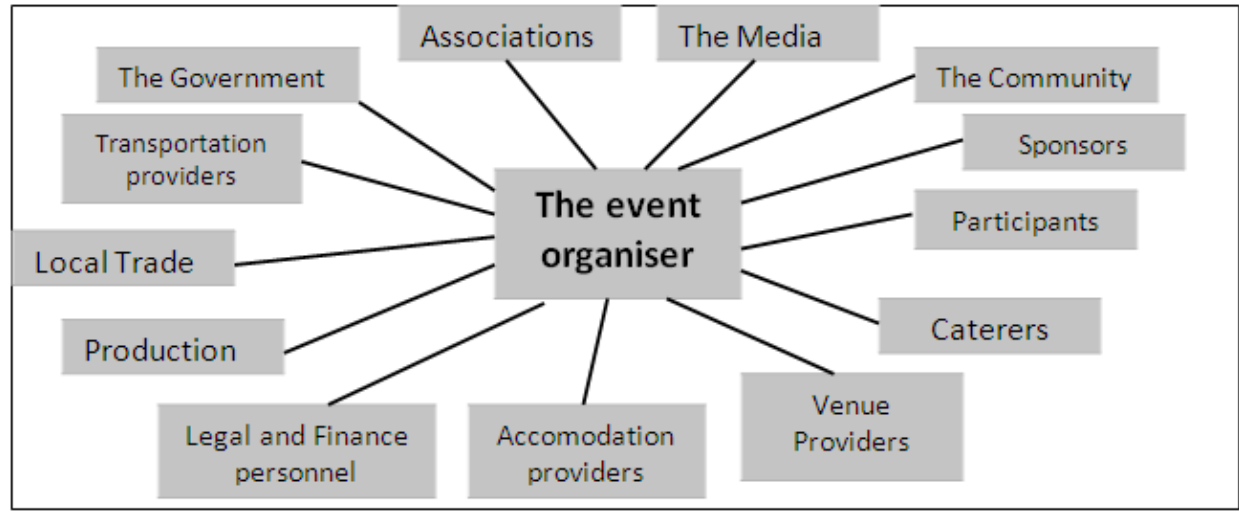

Gambar 1 Jaringan Event Stakeholder

(Glenn McCartney, 2010: 261)

Kehadiran event stakeholders untuk sebuah penyelenggaraan event Public Relations mempunyai arti penting. Kerja sama yang ada di antaranya akan saling menguntungkan kedua belah pihak. Kesuksesan sebuah event Public Relations adalah semakin banyaknya event tersebut dipublikasikan oleh berbagai media cetak dan elektronik dan tercakup di dalamnya jejaring sosial seperti facebook dan twitter yang sekarang sedang marak di masyarakat. Alangkah lebih baik lagi, event itu merupakan ajang yang sangat ditunggu oleh masyarakat misalnya ajang pencarian bakat yang diselenggarakan beberapa stasiun TV swasta bekerja sama dengan perusahan sponsor. Makin ramai diperbincangkan di media massa maupun jejaring sosial tentang isi acara itu maupun pengisi acara, akan makin baik untuk citra positif perusahaan penyelenggara. 
Kusumatuti dalam Dasar-dasar Humas (2002: 28) mengemukakan bahwa peran utama petugas Public Relations dalam kegiatan event adalah melakukan koordinasi selain terlibat dalam perencanaan dan negosiasi. Event yang besar bertaraf nasional maupun internasional penyelenggara akan melibatkan beberapa event organizer sekaligus. Tujuannya untuk mendapatkan event yang luar biasa. Event organizer akan berkolaborasi dan bekerja sama dengan pihak-pihak yang terlibat dapat memiliki manfaat dan juga sejumlah masalah akan dihadapi. Tabel berikut menunjukkan beberapa indikasi dari manfaat dan masalah yang mungkin saja terjadi pada kerja sama pengelolaan event.

Tabel 1 Potensi Manfaat dan Masalah dalam Kerja Sama Pengelolaan Event

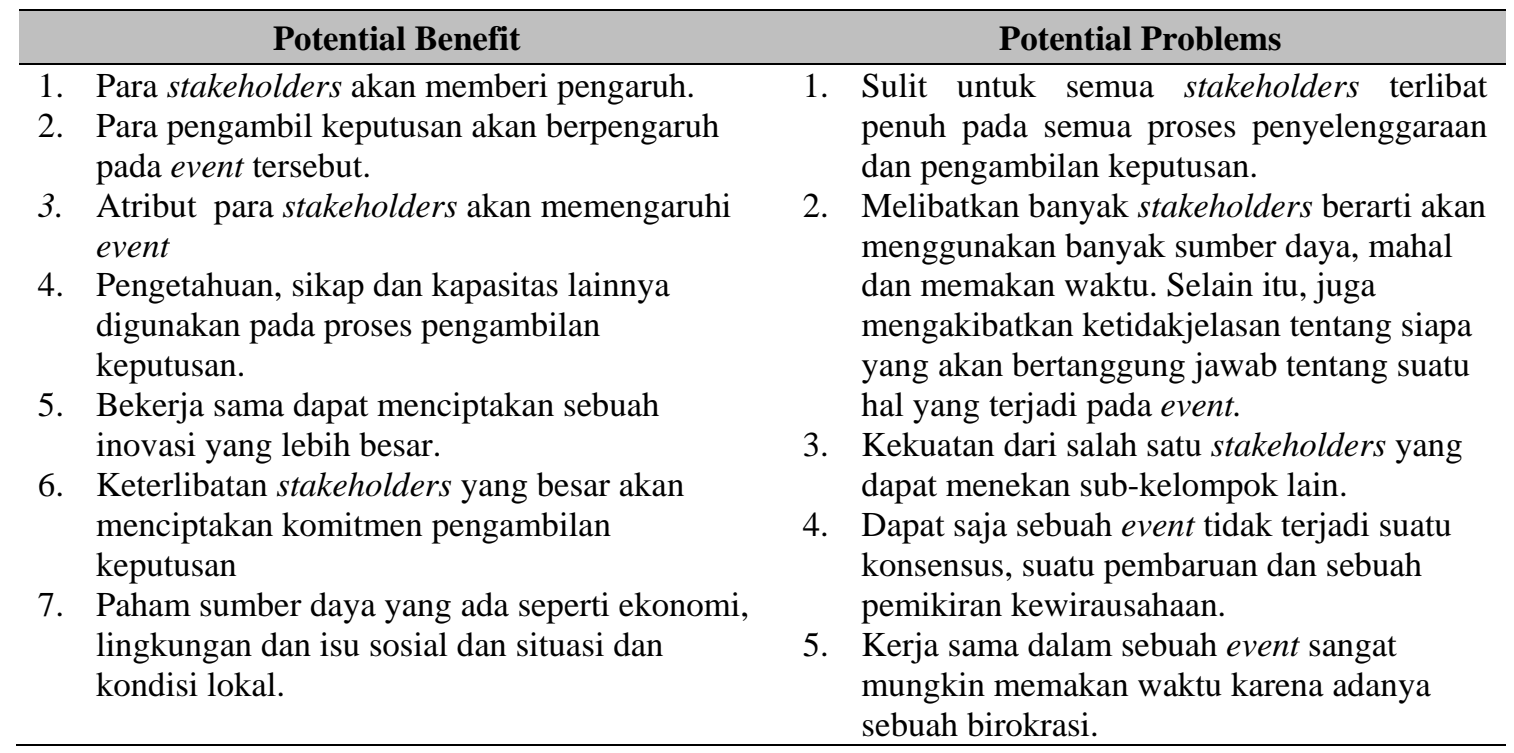

Berikut ini adalah keterlibatan stakeholders dan perannya masing-masing.

\section{Event Organizer}

Event organizer diperlukan bila perusahaan ingin mendapatkan sebuah event yang hendak dikelola secara profesional. Event organizer dapat pula bertindak sebagai konsultan perusahaan dalam hal pembuatan event maupun sekaligus sebagai pelaksana. Dapat saja terjadi kerja sama antar internal perusahaan dengan pihak eksternal yaitu event organizer. Event organizer memainkan peran sebagai koordinator dan menjalin komunikasi dengan berbagai suplier dan kontraktor yang terkait dengan event. Event organizer sebagai organisasi penyedia jasa penyelenggaraan event (Noor, 2009: 67).

Event organizer banyak membantu perusahaan untuk berbagai kegiatan seperti festival, pertandingan olahraga, pertunjukkan kesenian, product launches, conventions dan exhibitions. Fungsi event organizer di sini adalah sebagai koordinator event, negosiator dan konselor. Mereka perlu menyadari mengenai waktu dan anggaran mulai dari perencanaan hingga pelaksanaan. Event organizer terdiri dari orang-orang yang dapat memimpin dan mendorong timnya yang terdiri dari tenaga paruh waktu maupun staff fulltime. Bisa juga sebuah event menggunaakn tenaga sukarela. Meskipun mereka terdiri dari staf dan sebagian orang yang bekerja secara part time namun mereka harus mempunyai tanggapan yang positif. 


\section{Pemerintah}

Peran pemerintah dalam hal ini adalah sebagai suatu lembaga yang mendukung suatu event tersebut secara nasional maupun secara regional. Dalam hal ini, pemerintah mendukung event yang berkaitan misalnya dengan budaya, pariwisata, pendidikan, dan sebagainya. Kerja sama perusahaan dengan lembaga pemerintah tersebut dapat diwakili oleh kementerian yang menaunginya. Seperti untuk event yang berkaitan dengan teknologi komunikasi, kita dapat bekerja sama dengan kementerian komunikasi dan informatika. Contoh lain penyelenggaraan event yang berkaitan dengan event pameran edukasi tentu saja kita dapat bekerja sama dengan kementrian pendidikan nasional. Selain itu, lembaga pemerintah dapat kita libatkan adalah dalam masalah keamanan yaitu lembaga kepolisian.

Umumnya, bentuk kerja sama dengan berbagai lembaga pemerintahan dengan event organizer akan terkait dengan birokrasi untuk berbagai hal yang bersifat administratif. Perjanjian kerja sama merupakan hal yang tidak mudah karena di pemerintahan harus ada tanda tangan pemimpin tertinggi dan para wakilnya dan melalui tahapan tertentu. Hal ini sudah menjadi rahasia umum. Perlu waktu untuk mengajukan penandatanganan tersebut karena melalui berbagai tahapan dan proses tertentu. Untuk itu diperlukan lobi, negosiasi, dan diplomasi yang baik ketika kita mau mengadakan suatu kerja sama dalam penyelenggaraan event.

Manfaat yang kita peroleh dari kerja sama ini adalah event yang kita buat berskala nasional, atau paling tidak, berskala regional, artinya bukan bersifat lokal. Kemudian, event yang melibatkan pemerintah akan mendapat liputan media yang sifatnya nasional karena umunya setiap lembaga pemerintah sudah bekerja sama dengan sejumlah media massa cetak maupun elektronik dan lembaga itu juga sudah mempunyai media yang mereka kelola sendiri.

\section{Asosiasi}

Asosiasi yang terlibat dalam kerja sama event Public Relations, bersifat lokal bahkan sampai asosiasi tahap internasional. Alasan kita menggunakan asosiasi agar event yang kita selenggarakan dapat dihadiri oleh anggota asosiasi tersebut yang jumlahnya memang cukup banyak. Selain, itu asosiasi biasanya juga membantu dalam hal publikasi ke media, yaitu liputan tentang kegiatan asosiasi mereka. Asosiasi tersebut contohnya Rotary, Lions club, Ikatan Arsitek Indonesia (IAI), Ikatan Sarjana Komunikasi Indonesia (ISKI). Selain itu, keterlibatan asosiasi juga dapat membantu pengelolaan event yang berkaitan dengan budaya, agama atau bidang olahraga. Beberapa asosiasi mempunyai kerja sama dengan lembaga pemerintahan yang dapat menyediakan tambahan untuk internal promosi.

\section{Media}

Stakeholders media yang dapat bekerja sama dengan penyelenggaran event adalah media elektronik, media cetak dan masa kini banyak yang menggunakan media internet. Secara tradisional, media dapat menjadi "gatekeeper" atau penjaga gawang dari informasi yang akan disebarluaskan. Kehadiran internet melalui website dan blog menghadirkan informasi jurnalistik dan dapat melibatkan pengunjung untuk mengunggah video dan foto mereka secara otomatis.

Laporan dari para wartawan media massa dari stasiun televisi, pemancar radio, dan media internet akan berpengaruh pula kepada masyarakat dalam mengambil keputusan untuk mengunjungi event tersebut. Tugas dari tim Public relations adalah menciptakan dan menjaga komunikasi yang positif secara dua arah melalui media agar pengunjung menyadari bahwa event itu dapat mendorong minat pengunjung dan mempunyai citra positif pada perusahaan penyelenggara. 
Penyelenggara mampu menjalin kerja sama dengan media yang bertujuan untuk mendukung acara event yang melibatkan sponsor, pemerintah, masyarakat lokal, dan asosiasi. Program yang dapat dilaksanakan adalah mengunjungi media dan bertemu dengan para wartawan.

Dengan menggunakan media kit untuk progres atau kemajuan event, penyelenggara harus selalu memperbarui informasi seperti foto artis terbaru. Dari konsep event hingga event selesai perubahan yang terjadi pada event mulai dari panitia, keuangan, venue, program, partisipan. Selebriti, speakers dan laporan atau insiden dan krisis diinformasikan melalui elektronik newsletter.

Panitia perlu mengadakan Press conference dan menyediakan press release merupakan tugas penyelenggara agar dapat menghasilkan liputan media yang baik dan sesuai dengan harapan bagi event yang diselenggarakan. Nilai tambah dari event yang diselenggarakan dapat menghadirkan celebriti. Pemberian barang promosi dari event kepada para wartawan media juga mendapat nilai tambah selain mengemukakan bahwa event tersebut berkaitan dengan masalah-masalah kemanusiaan.

Penyediaan website adalah satu hal yang penting. Pada website, masyarakat dapat mengunduh foto-foto event, video, dan press release, informasi tentang event terbaru, dan forum diskusi serta masyarakat dapat mengirimkan permintaan kepada penyelenggarakan terkait dengan event tersebut. Contohnya, web event Kompas Gramedia http://www.kompasgramedia.com/events/read/33/kompasgramedia-fair-2012 yang berisi cara informasi jadwal acara harian Kompas Gramedia Fair, news release, jadwal event sepanjang tahun.

Media room atau media center digunakan untuk event topik tertentu atau skala tertentu. Biasanya, dibuat ruang eksklusif untuk media massa dan cetak. Di ruang ini diadakan rapat-rapat untuk awak media dan jumpa pers yang berkaitan dengan isu nasional maupun global. Pada ruang media ini penyelenggara menyediakan fasilitas peralatan komunikasi dan akses internet, mesin fax dan mesin fotokopi.

Tim $P R$ perusahaan dalam penyelengaraan event akan berkoordinasi dengan berbagai media. Informasi yang sampai ke media merupakan informasi yang terbaru sesuai dengan kondisi event. Bila penyelenggara bekerja sama dengan stakeholder dari pemerintah dan para sponsor lainnya, hendaknya mengadakan pertemuan terlebih dahulu sebelum informasi tersebut disebarluaskan. Informasi yang diberikan kepada pihak media hanya dari satu sumber saja, sehingga informasi tersebut akurat. Datadata yang diperlukan oleh pihak media juga harus merupakan persetujuan dari pihak stakeholder.

\section{Komunitas}

Ada sejumlah alasan dan motivasi anggota dalam komunitas untuk terlibat dalam sebuah event. Komunitas terdiri dari berbagai sektor seperti kaum muda, manula atau business leaders. Faktor-faktor yang mendorong mereka untuk terlibat adalah: (1) having fun: alasan utamanya event akan menikmati suatu atmosfer yang menyenangkan dnegan berinteraksi dengan pengunjung lainnya, menonton pertunjukkan, dan mempunyai suatu kesan yang tak terlupakan (have a memorable time); (2) support: anggota komunitas tidak menginginkan event tersebut gagal. Mereka akan mendukung seluruh rangkaian acara; (3) education, knowledge, achievement and advancement: berbagai keahlian dan pengetahuan diperlukan. Komunitas yang sudah maju memerlukan program seperti keahlian komputer, bahasa dan guest relations, menangani media, protokoler dan logistik seperti transportasi; (4) Appreciation of arts and sports: event budaya, seni dan olahraga mempunyai peluang untuk menginspirasi mereka; (5) Audience development: seni atau olahraga dapat mengembangkan minat masyarakat lokal untuk bergabung pada klub atau asosiasi setelah event selesai; (6) Reinforcing community identity and links to enviroment: dengan keterlibatan masyarakat lokal, event mengangkat budaya lokal dari masyarakat setempat dan membuat masyarakat lebih menyadari mengenai identitas budaya dan menghargainya; (7) Economic Gain: penduduk sekitar akan mendapatkan keuntungan dari 
event tersebut dengan berjualan suvenir, makanan dan minuman selama event berlangsung di sekitar area event. Jasa perusahaan lokal seperti desain, produksi dan perusahaan entertainment akan merangsang ekonomi selama event berlangsung. Seperti contohnya pada waktu Sea Games XXVI 2011 di kota Palembang, banyak perusahaan lokal yang terlibat pada persiapan dan pelaksanaan event olahraga terbesar di Asia Tenggara (Mc Cartney, 2010: 271).

\section{Sponsor}

Dalam konsep baru, dalam jurnal ilmiah humaniora Binus University, diungkapkan bahwa para sponsor tidak hanya memberikan uang atau barang dan jasa saja. Para sponsor berperan aktif untuk kesuksesan event tersebut (Evelina, 2011: 989). Sponsor memberikan kontribusi yang sangat penting dalam penyelenggaraan event, namun sponsor dalam hal ini tidak hanya dalam hal finansial saja. Sponsor dapat terlibat dalam hal barter atau penyediaan hotel, transportasi, dan lainnya. Sponsor diperlukan dengan berbagai alasan diantaranya dengan kehadiran sponsor dapat menambah pengaruh kepada pengunjung event karena event itu semakin semarak dengan berbagai penampilan dari pihak sponsor. Para sponsor juga akan membantu mempromosikan event melalui above the line maupun bellow the line seperti berbagai ragam atribut seperti $t$-shirt, topi, stationery, dan sebagainya. Sponsor juga akan mengekspos keterlibatannya dalam event di berbagai media massa cetak, elektronik dan on line media, serta media internal sponsor. Dengan demikian, perusahaan sebagai penyelenggara event akan terbantu promosinya dan eksistensinya di masyarakat umum.

Siapa saja yang bersedia menyediakan sponsor pasti ingin agar jati diri atau lembaganya meraih reputasi mengesankan, memiliki nama harum, atau agar dikenal secara luas. Dengan demikian, pada dasarnya setiap penyediaan sponsor selalu mengandung fungsi kehumasan. Terdapat begitu banyak alasan sponsor, tetapi pada dasarnya semua alasan itu pasti mengandung tujuan-tujuan humas, yakni menunjukkan niat baik dan menciptakan suatu pemahaman positif di kalangan khalayak, atau mengetahui keberadaan perusahaan atau lembaga penyedia sponsor. Hal inilah yang perlu ditekankan ketika mengajak peran serta sponsor untuk berpartisipasi pada sebuah event (Anggoro, 2008: 199).

Bila perusahaan menyelenggarakan event yang berkaitan dengan isu sosial dan lingkungan ini akan menggerakkan para sponsor untuk berpartisipasi sebagai bentuk Corporate Sosial Responsibility (CSR) dari perusahaan sponsor. Isu yang bisa dikaitkan dengan event adalah edukasi, kesejahteraan, event charity, perlindungan lingkungan atau event yang berkaitan kesehatan dan isu sosial seperti anti-rokok dan anti-obat-obatan terlarang. Kegiatan marketing sosial ini akan menunjukkan tanggung jawab kepada masyarakat setempat dan merupakan strategi yang positif karena akan menjadi arah pembicaraan di masyarakat (word of mouth).

Strategi untuk mendapatkan sponsor tidak hanya semata untuk mendukung finansial, tetapi bisa diarahkan kepada program barter produk maupun jasa dari para sponsor tersebut. Para sponsor itu bisa kita dapatkan dari hotel, airlines, car rental, caterers, perusahaan publishing, production house, venue providers, souvenir dan perusahaan IT yang menyediakan produk, jasa dan tenaga ahli dengan harga khusus bahkan gratis. Mereka hendak mensponsori suatu acara karena ingin brand exposure atau brand awareness bahkan brand recognition. Event yang sukses dibanjiri pengunjung juga berdampak positif pada para sponsornya.

Dalam Event Management an Asia Perspective, sponsorship merupakan salah satu strategi promosi yang cocok untuk saat ini. Sponsorship jangka panjang dikatakan sebagai salah satu bentuk investasi untuk mencapai tujuan perusahaan dalam membentuk citra positif di masyarakat (Mc Cartner, 2007: 274).

Event yang berhasil akan menjadi perbincangan positif di masyarakat sehingga menimbulkan hasil yang positif pula bagi perusahaan sponsor dan juga perusahaan penyelenggara. Para konsumen 
akan mencari informasi mengenai produk dan jasa dari kedua perusahaan tersebut dari pemberitaan maupun artikel di media massa. Ini merupakan suatu pendekatan yang kreatif dari perusahaan sponsor dengan target audiensinya. Secara keseluruhan para sponsor mungkin terlibat dalam berbagai hal seperti penyediaan tiket box, tenda, membantu menjual tiket, mengundang pembicara, menghadirkan pejabat pemerintah, media, suppliers dan para investors pada event. Jelas terlihat bahwa event itu menjadi ajang yang sangat bergengsi.

Jumlah sponsor dapat kita batasi sesuai dengan yang kita butuhkan. Sebuah event hanya membutuhkan satu sponsor tunggal yang membiayai bertanggung jawab atas seluruh biaya pelaksanaan event. Untuk sistem barter kita harus terlebih dahulu menghitung barang atau jasa ke dalam bentuk uang supaya jelas mengenai kompensasi promosi yang akan diberikan. Terlalu banyak sponsor juga akan menimbulkan kesan yang negatif bagi event. Kerja sama event organizer dan sponsor merupakan kerja sama saling menguntungkan. Apapun tipe sponsor yang dipakai oleh event organizer memerlukan proses dari proposal hingga laporan hasil evaluasi kepada sponsor.

\section{Participants}

Partisipan yang dimaksud di sini adalah pengisi acara seperti speakers, atlet, atau aktor dan aktris yang akan tampil pada event tersebut. Hal yang perlu diperhatikan adalah waktu mereka tampil dan keamanan selama mereka berada pada event yang berlangsung. Partisipan yang dibayar dan diundang untuk menghadiri event tersebut berdasarkan jumlah yang tempat/kursi yang tersedia. Para undangan seperti para sponsor, media, perwakilan dari pemerintah, tamu VIP memerlukan protokoler dan petugas khusus untuk mengatur dan menjaga keamanan mereka. Pada event akan disiapkan petugas khusus yang berjaga di area tamu undangan ini.

Para undangan perlu disediakan pula sejumlah petugas khusus penerima tamu dan meja untuk penerimaan para undangan. Kemudian perlu juga disediakan area parkir khusus tamu undangan dan bebas biaya parkir. Makanan dan minuman pun harus diseleksi sebelum diberikan kepada para tamu undangan khusus. Selain itu, penyelenggara perlu menyediakan profil para tamu untuk diberikan kepada para peliput berita dari berbagai media. Fotografer akan disediakan khusus selama event berlangsung untuk meliput aktivitas para partisipan tersebut.

\section{Jasa Katering (Caterer)}

Untuk penyediaan katering, pihak penyelenggara harus mengetahui jumlah dari peserta yang hadir. Caranya adalah kita meminta konfirmasi akan kehadiran anggota komunitas organisasi atau lembaga yang berencana, atau yang diundang untuk hadir.

\section{Numbers Attending}

Umumnya, perhitungan jumlah makanan yang akan disediakan adalah berdasarkan jumlah para partisipan yang dikonfirmasikan akan datang. Namun panitia harus menambahkan ekstra jumlah makanan untuk antisipasi partisipan yang langsung datang ke event. Makanan juga disiapkan untuk pengisi acara, fotografer, dan staf secara terpisah maupun digabung dengan para undangan. Jangan menyiapkan terlalu banyak sehingga tersisa banyak dan juga hindari kekurangan makanan karena akan merusak citra event tersebut dan menimbukan kesan kurang baik.

\section{Equipment}

Katering memerlukan persiapan peralatan seperti berbagai macam gelas untuk minuman yang berbeda, misal gelas untuk air putih, gelas untuk minuman soft drink, dan gelas untuk sirup. Peralatan lain yang perlu disiapkan adalah serbet, garnish atau hiasan untuk makanan, pembuka botol 
minuman, blenders, ice buckets, dan peralatan untuk meja makan lainnya. Untuk itu, diperlukan daftar periksa mengenai segala peralatan yang dibutuhkan.

\section{Oustside Catering}

Jika menggunakan jasa katering dari luar, hal yang perlu diperhatikan adalah mengenai transportasi untuk mengangkut makanan tersebut. Penggunaan jasa katering dari luar ini lebih mahal dari pada menyiapkan sendiri.

\section{Local Product}

Menggunakan produksi lokal lebih murah dan menguntungkan masyarakat sekitar seperti sayuran, buah-buahan, dan daging dari pasar tradisional. Untuk event yang besar, mungkin saja ketersediaan jumlah bahan makanan dari produksi lokal tidak mencukupi sehingga harus menambahkan dari supermarket.

\section{Menu Selection}

Bila event berlangsung dalam beberapa waktu, seperti konvensi atau konferensi, panitia harus menyeleksi beberapa variasi menu. Setiap hari panitia sebaiknya menyediakan menu yang berbeda. Variasi menu akan menjadi perbincangan antara partisipan, jika menu tersebut memiliki kesan tersendiri. Pilihan untuk menggunakan menu produksi masyarakat lokal menjadi pertimbangan tersendiri. Panitia juga perlu mempertimbangkan faktor pilihan seperti partisipan yang hanya makan vegetarian food, religious food untuk agama tertentu yang menyangkut makanan tersebut halal, perlu diperhitungkan.

\section{Standing atau Sitting}

Makan dengan sistem standing adalah partisipan tidak dapat memegang makan dan minuman dalam jumlah banyak. Bagian Banquets akan menyediakan beberapa petugas yang membantu mendistribusikan makanan kepada para undangan. Sistem Buffets lebih popular, tetapi harus antre dalam mengambil makanan. Sistem makan berdiri memungkinkan para tamu untuk menyebar. Sedangkan sistem duduk akan membuat tamu mengantre hanya pada satu tempat untuk beberapa waktu.

\section{Participant Behavior}

Untuk event olahraga, perbanyak counter makanan untuk memperpendek antrean karena para peserta ingin cepat memperoleh kesegaran kembali setelah pertandingan. Antrean yang singkat juga tidak mengganggu jadwal start pertandingan. Event organizer perlu memerhatikan jadwal pertandingan dan menyiapkan makanan dan minuman seusai pertandingan berlangsung.

\section{Staffing}

Staff Banquet yang ditempatkan untuk mengurusi makanan dan minuman harus mendapatakan training secara profesional dan orang yang dipilih adalah orang yang berpengalaman. Petugas seperti waiter juga berpenampilan rapi, bersih, demikian pula untuk rambut wanita harus diikat ke belakang dan tidak menggunakan perhiasan yang berlebihan supaya tidak menggangu aktivitas kerja. Sikap staf akan memberi kesan baik pada para tamu yang hadir. 


\section{Smoking Policy}

Harus dibedakan area yang boleh merokok dan area yang tidak boleh merokok dan event organizer selalu memantau dengan menempatkan tamu sesuai dengan kondisi mereka.

\section{Food Safety}

Untuk menghindari keracunan makanan, maka perlu menjaga kebersihan makanan termasuk menutup makanan dengan tepat dan menyimpan makan dalam suhu yang tepat pula.

\section{Stock Control}

Pada katering event yang besar, berarti harus disiapkan makanan dan minuman untuk beberapa hari. Petugas selalu memantau yang belum dan sudah terpakai.

\section{Cut off Times}

Katering harus disiapkan dua jam sebelum event diselenggarakan. Event organizer harus mengatur agar tidak melebihi waktu untuk penyediaan makanan dan minuman (McCartney, 2010: 280-281).

\section{Venue Providers}

Penyedia tempat penyelenggaraan disesuaikan dengan tema dan tujuan event tersebut. Kesesuaian dan kenyamanan pengunjung juga menjadi pertimbangan dalam hal memilih tempat penyelenggaraan. Venue akan didesain sesuai dengan kebutuhan event dapat diselenggarakan di dalam ruangan (indoor) maupun di luar ruangan (outdoor). Event yang diselenggarakan di dalam ruangan lebih mudah untuk menangani pengunjung dibanding dengan event yang diselenggarakan di luar ruangan. Risiko event luar ruangan lebih tinggi karena sulit untuk mengontrol keadaan pengunjung ketika event berlangsung.

Pertimbangan pemilihan venue meliputi berbagai hal, di antaranya yaitu persepsi terhadap image dari event tersebut, misalnya event yang diselenggarakan di hotel berbintang lima jauh lebih bergengsi daripada event yang diselenggarakan dengan menggunakan hotel berbintang tiga. Ukuran dan kapasitas gedung atau venue untuk menampung pengunjung perlu diperhitungkan dalam mempertimbangkan pemilihan venue, disesuaikan dengan jumlah undangan dan perkiraan pengunjung tidak perlu berlebih. Lahan parkir yang disediakan oleh venue juga perlu diketahui berapa jumlah kendaraan yang bisa tertampung. Kemudian, alat transportasi yang bisa menuju venue tersebut, apakah tempat tersebut dilalui oleh bus atau alat transportasi lainnya. Penyelenggara juga perlu mengecek fasilitas seperti toilet dalam keadaan baik dan dalam jumlah mencukupi, mesin ATM, area meeting points dan akses internet (wi-fi), kantin dan restoran. Hal yang tak kalah penting lainnya adalah fasilitas tambahan yang disediakan oleh pihak venue meliputi soundsystem, lighting equipment termasuk tenaga teknisinya, staf penerima tamu (resepsionis). Semuanya tergantung dari negosiasi antara pennyelenggara dengan pihak venue. Ketua penyelenggara harus memiliki pengetahuan dan familiar dengan berbagai aspek yang terkait dengan venue. Ketua panitia perlu mendapat informasi yang lengkap dan detail service yang diberikan oleh pihak venue sebelum menentukan pilihan.

\section{Accomodations Providers}

Penyediaan sarana akomodasi diperlukan bila selama event diperlukan penginapan dari luxurius hotel atau akomodasi dengan gaya boutique. Tipe ruangan juga mulai dari standar sesuai dengan anggaran. Standar yang digunakan untuk sebuah event di dalam kota biasanya hotel bintang 
tiga. Akomodasi yang lain, di luar kota, bisa menggunakan resort dengan ukuran ruang yang lebih besar.

Berikut ini beberapa faktor untuk menjadi pertimbangan dalam pemilihan akomodasi: (1) accomodation and venue connected; merupakan akses yang membuat partisipan merasa nyaman. Bila hotel yang digunakan adalah official hotel, semua keperluan partisipan akan diurus oleh panitia. Namun bila partisipan ingin menggunakan hotel atau penginapan lain, semua biaya dan keperluan selama menginap merupakan tanggung jawab masing-masing partisipan. (2) Peak or off-peak; bila event menggunakan off-peak season untuk skala besar, lebih baik untuk negosiasi dengan harga khusus. (3) Number of rooms; event manager atau ketua penyelenggara akan mendiskusikan mengenai ruangan yang diinginkan, misalnya jumlah kamar dengan twin bed atau jumlah kamar dengan double bed dan kamar yang termasuk complimentary room dan biasanya pihak hotel akan memberikan 1 (satu) kamar bebas biaya (free) untuk panitia selama event berlangsung di hotel tersebut. Pihak hotel juga bisa memberikan 1 (satu) kamar gratis untuk 10 kamar yang dipesan bila acara diselenggarakan menggunakan fasilitas hotel, semuanya tergantung dari negosiasi dengan pihak management hotel. (4) Type of rooms; karakteristik kamar mulai dari yang sederhana hingga yang mewah, mulai dari lower floors hingga higher floors. Menurut kepercayaan orang Cina, lantai dengan angka 3 atau lantai angka 8 merupakan lucky number atau nomor keberuntungan. Karakteristik yang lain seperti sea views, nonsmoking atau women-only floor perlu diinformasikan sebelumnya. (5) Room cut-off; khusus untuk para partisipan dan tamu undangan event tersebut akan diberikan harga khusus selama event berlangsung dan beberapa hari setelah event selesai. (6) Contractual term; meliputi hari dan waktu, harga sewa kamar hotel, waktu check in dan waktu check out, sistem pembayaran dengan harga net atau harga gross dan biaya tambahan, biaya keterlambatan. (7) Transfers; hotel menyediakan shuttle bus atau kendaraan yang akan menjemput partisipan. (8) Welcome arrangements; panitia dapat mengatur untuk menyediakan banner berisi ucapan selamat datang atau kalungan bunga selamat datang kepada para tamu di lobi, juga menyediakan minuman selamat datang dan personalised letter dari manajer hotel ini akan membuat tamu undangan merasa spesial. Hotel juga dapat mengibarkan bendera hotel sebagai sambutan kepada para tamu undangan. (9) Facilities use; fasilitas yang digunakan seperti kolam renang, gyms dengan diskon atau free of charges. Biasanya sewa kamar berikut sarapan pagi, tetapi perlu diinformasikan sejak awal. Kemudian, apakah juga termasuk diskon atau voucher restoran untuk makan siang dan makan malam (McCartney, 210: 286-289).

\section{Legal and Finance Personnel}

Untuk sebuah event tertentu, pada umumnya juga diperlukan jasa legal seperti untuk asuransi untuk event tersebut, kontrak kerja sama dengan berbagai pihak yang terlibat dalam pembuat event, perizinan dengan pihak keamanan dan lisensi bila diperlukan. Gunakan jasa pengacara untuk kontrak event untuk sahnya suatu perjanjian. Tenaga-tenaga part time juga memerlukan sebuah kontrak untuk menghindari kesalahpahaman dan tugas yang mereka terima.

Event organizer dan pihak venue juga mengatur mengenai masalah event yang ditunda atau dibatalkan dengan kompensasi yang disepakati. Demikian pula dengan kontraktor. Orang-orang yang bekerja di belakang panggung diperhitungkan sesuai dengan anggaran, termasuk pembelian untuk dekorasi panggung, event lighting, tanaman hias, back drop dan perlengkapan event lainnya.

Kontrak seperti yang ditulis Lynn Van der Wagen dan Brenda R. Carlos dalam buku Event management tersebut berisi pasal-pasal sebagai berikut: pihak yang mengadakan perjanjian, deadline dan deposit, spesifikasi seperti space booked, timing, food and beverage, akomodasi, jasa yang disediakan, jadwal pembayaran, asuransi, pembatalan, termination/nonperformance, kejadian yang tidak diperkirakan/post-majeur, konsumsi, kerahasiaan yang harus dijaga, abitrase bila terjadi sengketa, jaminan, dan tanda tangan dan tanggal pembuatan (Van der Wagen, 2005: 57). 


\section{Production}

Untuk menyiapkan artwork dan design event kita memerlukan perusahaan kontraktor dan production house. Artwork misalnya termasuk concert backdrops, banners, petunjuk pada venue, outdoor advertising seperti banner dan billboard atau giant board dan bentuk kreatif lainnya atau balon udara. Produksi juga dapat mengerjakan beraneka macam material seperti tiket atau kartu untuk masuk ke area event, program, stationary, newsletter, posters and flyers. Seragam, merchandise dan souvenir dapat juga diserahkan kepada kontraktor.

Event organizer hanya memastikan semua artwork dengan benar sesuai dengan dimensi, warna, logo, kata-kata dan bentuk huruf dan jangka waktu dan hanya orang yang mempunyai otoritas yang dapat membuat keputusan dan mengubahnya bila diperlukan. Perlu diwaspadai mengenai masukan yang terlalu banyak sehingga menimbulkan revisi pada artwork akan memperpendek waktu penjadwalan produksi. Untuk mendapatkan hasil yang terbaik dan maksimal, Event organizer melakukan bids atau tender untuk lebih dari satu pemasok ( Locicero, 2008: 42).

\section{Transportation Providers}

Pelaksana atau panitia perlu menyediakan jasa tranpostasi lokal untuk para tamu, pengisi acara dan partisipan acara seperti pesawat, transportasi kereta api, bis, transportasi kapal atau feri, taksi, alat transportasi lokal lainnya. Pastikan keamaanan dari alat transportasi tersebut dan penyelenggara dan penyedia transportasi perlu membuat semacam kontrak tertulis yang menjelaskan hak dan kewajiban selama transportasi tersebut digunakan. Jumlah seat pada bis ditulis dalam perjanjian dan fasilitas yang disediakan misalnya TV, video, Toilet, $A C$ termasuk penyediaan konsumsi.

Untuk event yang menghadirkan pengunjung dari mancanegara, kadang-kadang guide atau petugas khusus akan menyediakan alat tukar uang (money changer) untuk memudahkan pengunjung yang belum sempat atau kekurangan uang untuk digunakan sebagai transaksi di suatu negara. Hal lain yang perlu dicantumkan pada surat perjanjian adalah mengenai pengurusan bagasi, keselamatan dan keamanan, kebersihan toilet. Penyelenggara akan mengatur kendaraan yang cocok dengan karakteristik pengunjung dan juga memerhatikan jumlah kendaraan yang bisa disediakan dan infrastruktur yang ada seperti tempat pemberhentian atau transit kendaraaan. Pengunjung disiapkan driver yang terlatih, sopan, dan memiliki keterampilan bahasa yang sesuai dengan pengunjung. Kerja sama untuk bidang transportasi ini dapat dilakukan dengan biro perjalanan karena mereka memiliki hubungan dengan penyedia jasa transportasi tersebut.

\section{Pasca-event}

Setelah event dinyatakan selesai, laporan kepada stakeholders perlu dibuat. Isi laporan tersebut mencakup: nama dan tema event; misi dan tujuan; lokasi acara, tempat/venue, tanggal dan waktu; program rundown; data harga tiket dan jumlah yang terbayar, komplementari dan tiket VIP; profil partisipan; catatan dan notulen rapat-rapat kepanitiaan; akomodasi, makanan dan minuman serta hiburan; salinan dari material cetak seperti brosur, flyer, tiket dan poster; dokumentasi foto dan video; daftar rekanan dan para sponsor; daftar tamu kehormatan; rencana anggaran dibandingkan dengan aktualisasi anggaran; tayangan iklan; kliping berita atau artikel yang dimuat media massa, cetak maupun elektronik; daftar jasa kontraktor; perencanaan jadwal dan aktualisasi jadwal, sesuai atau ada perubahan; daftar dari kontak-kontak yang dilakukan; evaluasi dari partisipan dan stakeholder lainnya; simpulan dari semua pelaksanaan event. Penulisan laporan akhir sebagai acuan untuk event mendatang, bahwa, setiap event harus unik atau event yang akan datang selalu ada perbaikan dari event sebelumnya. Event yang hanya merupakan replikasi dari event sebelumnya akan kurang daya tariknya bagi pastisipan dan stakeholder. 


\section{SIMPULAN}

Simpulan yang bisa ditarik dari penelitian ini, yaitu: pertama, setiap stakeholder mempunyai kontribusi masing-masing dan memerlukan tenaga profesional yang terlatih dan penyelenggara harus berkoordinasi, berkomunikasi secara teratur, dan mendiskusikan masalah-masalah yang dihadapi selama proses event berlangsung. Kedua, kolaborasi dengan stakeholders dalam sebuah event Public Relations dapat dilakukan dengan event organizer, pemerintah, asosiasi, media, komunitas, sponsor, participants, jasa katering (caterers), venue providers, accomodations providers, legal and finance personnel, production, dan transportation providers. Masing-masing mempunyai peranan yang penting jadi perlu adanya komunikasi dan koordinasi rutin dengan host atau tuan rumah sesuai dengan perkembangan yang terjadi. Ketiga, bekerja sama dengan stakeholders tidak semua bisa menyenangkan mereka. Kadang kala ada hal yang tidak bisa dipenuhi, untuk itu perlu adanya perjanjian. Kontribusi yang sesuai dengan harapan dari pihak penyelenggara yang diwakili petugas $P R$ dan stakeholders akan menghasilkan event yang baik dan berdampak terhadap citra perusahaan. Terakhir, keempat, setelah event selesai, panitia membuat laporan akhir, mulai dari rencana, pelaksanaan hingga evaluasi event kepada stakeholders.

\section{DAFTAR PUSTAKA}

Anggoro, L. M. (2008). Teori Profesi \& Kehumasan serta Aplikasinya di Indonesia. Jakarta: Bumi Aksara.

Dandjaja. (2011). Peranan Humas dalam Perusahaan. Cetakan Pertama. Yogyakarta: Graha Ilmu.

Evelina, L. (2011). Paradigma Baru sponsor sebagai Mitra penyelenggara Event. Jurnal Ilmiah Humaniora. Volume 2 no. 2. Jakarta: Binus University.

Kusumatuti, F. (2002). Dasar-dasar Humas. Jakarta: Ghalia Indonesia.

LoCicero, J. (2008). Meeting and Event Planning. USA: F+ W Publication.

Mc Cartney, G. (2010). Event Management an Asian Perspective. Singapore: Mc Graw Hill.

Noor, A. (2009). Manajemen Event. Bandung: Alfabeta.

Pauline, G. (2011). Volunteer Satisfactions and Intent to Remain an Analysis of Contributing Factors among Professional Golf Event Volunteers. International Journal of Event Management Research. Volume 6, Number 1, 2011. Diakses dari http://www.ijemr.org/docs/Vol61/Pauline.pdf.

Van Der Wagen, L., dan Carlos, B. R. (2005). Event Management. For Tourism, Cultural, Business, and Sporting Events. New Jersey: Pearson Education. 